\title{
ANTIMICROBIAL ACTIVITY OF ENDOPHYTIC FUNGI FROM COFFEE PLANTS
}

\author{
ATIVIDADE ANTIMICROBIANA DE FUNGOS ENDOFÍTICOS DE PLANTAS DE \\ $C A F E ́$
}

\section{Mônica Cristina Pereira MONTEIRO' ${ }^{\text {; }}$ Natálie Martins ALVES ${ }^{1}$; Marisa Vieira de QUEIROZ²; Danilo Batista PINHO³; Olinto Liparini PEREIRA ${ }^{4}$; Sara Maria Chalfoun de SOUZA ${ }^{5}$ Patrícia Gomes CARDOSO ${ }^{1}$}

1. Department of Biology, Federal University of Lavras, Lavras, MG, Brazil; 2. Department of Microbiology, Federal University of Viçosa,Viçosa, MG, Brazil; 3. Department of Plant Pathology, University of Brasília, Distrito Federal, DF, Brazil; 4. Department of Plant Pathology, Federal University of Viçosa,Viçosa, MG, Brazil; 5. Agricultural Research Company of Minas Gerais, Tech Center South Minas, Lavras, MG, Brasil. patricia@ dbi.ufla.br

\begin{abstract}
Endophytic fungi are a promising source for discovery of compounds with biotechnological potential. The aim of this study was to select and identify endophytic fungi from Coffea arabica that produce volatile organic compounds (VOCs), evaluate the effect of the VOCs produced by endophytic fungi on the growth of Rhizoctonia solani, Fusarium oxysporum, Phoma sp., Botrytis cinerea, Fusarium solani, Fusarium verticillioides, Cercospora coffeicola and Pestalotia longisetula, and select endophytic fungi with potential for biological control of Aspergillus ochraceus inoculated in coffee beans and F. verticillioides inoculated in corn seeds. An isolate of Muscodor albus was used as selection tool for VOC producing fungi. Among the 400 endophytic fungi isolates, 11 were able to grow in the presence of VOCs produced by M. albus. These fungi were identified as Muscodor spp. (9) and Simplicillium sp. according to searches in UNITE database using DNA sequences of internal transcribed spacer (ITS). The VOC's produced by endophytic fungi inhibited the growth the phytopathogenic fungi with different efficacies, compared to the control. The VOCs produced by Muscodor coffeanum (COAD 1842) showed fungicidal effect against A. ochraceus on coffee beans. Six endophytic fungi completely inhibited growth of $F$. verticillioides inoculated in corn seeds. This study demonstrates that the volatile-compound producing endophytic fungi, isolated from Coffea arabica, are promising sources of bioactive compounds.
\end{abstract} compounds.

KEYWORDS: Aspergillus ochraceus. Fusarium verticillioides. Inhibition. Muscodor spp. Volatiles

\section{INTRODUCTION}

Endophytic fungi colonize living tissues of various plants, establishing mutualistic relationship without causing any symptom of disease (PETRINI, 1991; AZEVEDO et al., 2000; HYDE; SOYTONG, 2008). Their distribution within plants is ubiquitous but varies according to plant tissue (root, leaf, stems and fruits) and from strain to strain (TAN; ZOU, 2001). Endophytes have received considerable attention because of their ability to produce several novel compounds including terpenoids, alkaloids, phenylpropanoids, polyketides, aminoacids, and phytohormones (STROBEL et al., 2001; TEJESVI et al., 2007).

Some metabolites produced by endophytic fungus can help the host plant to tolerate biotic and abiotic stress, protect plants against diseases and from insect and nematode attack, as well as favor the growth of crop plants (KOGEL et al., 2006). In addition, endophytic fungi have been reported to reduce the growth of the different phytopathogenic fungi (EZRA; STROBEL, 2003; ZHANG et al.,
2010; SUWANNARACH et al., 2012; SAXENA et al., 2015). Muscodor species produce a mixture of volatile organic compounds that open new possibilities for the biological control of microbial decay in food and agriculture by biofumigation (STROBEL et al., 2001; DAISY et al., 2002; MERCIER; SMILANICK 2005; GRIMME et al., 2007).

Studies have been conducted with endophytes using species of plants that have economic significance, especially coffee crops (SANTAMARIA; BAYMAN, 2005; VEGA et al., 2005a, 2006b, SETTE et al., 2006a; SAUCEDOGARCIA et al., 2014). Due to the economic importance of this crop and biotechnological potential of endophytic fungi, the aims of this study were to isolate and identify endophytic fungi from Coffea arabica in Brazil that produce volatile organic compounds (VOCs), evaluate the effect of the VOCs produced by endophytic fungi on the growth of phytopathogenic fungi and select endophytic fungi with potential for biological 
control of A. ochraceus in coffee beans and $F$. verticillioides in corn seeds.

\section{MATERIAL AND METHODS}

\section{Sample collection and isolation}

Field surveys were carried out during 2011 in the Zona da Mata region, Viçosa municipality, Minas Gerais, Brazil to obtain endophytic fungi on organic coffee plantations. Coffee tissue parts were rinsed in sterile distilled water for $1 \mathrm{~min}$ and dried. Small pieces $(4-5 \mathrm{~mm})$ of apparently healthy tissue were then disinfected in $70 \%$ ethanol for $1 \mathrm{~min}$ followed by $2.5 \%$ sodium hypochlorite for $3 \mathrm{~min}$ and washed in sterile distilled water. Fragments were placed in Petri dishes with Potato Dextrose Agar (PDA - Acumedia ${ }^{\circledR}$ ) amended with chloramphenicol $100 \mathrm{ppm}$ and incubated at $25^{\circ} \mathrm{C}$. Hyphal tips of fungal colonies emerging from plant tissue pieces were transferred to PDA dishes and incubated at $25^{\circ} \mathrm{C}$. The cultures were stored in tubes on PDA at $10^{\circ} \mathrm{C}$.

\section{Screening of VOC producing isolates}

Screening of endophytic fungi that produce VOCs was made as described by Strobel et al., (2001) with modifications. A culture of the original isolate of M. albus (strain CZ620) was used as selection tool for VOC producing fungi. Muscodor albus was placed and grown on one side of the plate for 7 days at $25^{\circ} \mathrm{C}$. A mycelial disk of each endophytic isolate (5 mm diameter) was deposited on the opposite side. Each isolate was tested in three replicates. The plate was wrapped with Parafilm ${ }^{\circledR}$ and incubated at $25^{\circ} \mathrm{C}$ for one week. The experiment was performed twice and only isolates able to grow in the presence of VOCs produced by M. albus were selected for identification.

\section{Molecular identification}

The genomic DNA was extracted from pure cultures grown on PDA using a Wizard ${ }^{\circledR}$ Genomic DNA Purification Kit (Promega Corporation, WI, U.S.A). The internal transcribed spacer (ITS) was amplified using primers ITS1 and ITS4 (WHITE et al., 1990). PCR products were purified and sequenced by Macrogen, South Korea. The sequences were edited using BioEdit software (HALL, 1999). A BLAST search was performed to check for similarity with other sequences and identification was performed according to searches in UNITE database (NILSSON et al., 2014).

\section{Bioassay for volatile antimicrobials}

The inhibitory antimicrobial activity of VOCs produced by endophytic fungi from coffee was tested against the following phytopathogenic fungi: Rhizoctonia solani (LAPS 369), Fusarium oxysporum (LAPS 152), Phoma sp. (DFP 01), Botrytis cinerea (LAPS 300), Fusarium solani (LAPS 298), Fusarium verticillioides (CML 1896), Cercospora coffeicola (CML 2984) and Pestalotia longisetula (DFP 02). Endophytes were cultivated in PDA medium in Petri dishes and incubated at $25^{\circ} \mathrm{C}$ for 7 days. After this period, the phytopathogenic fungi were transferred to the other side of the plate. The plates were incubated at $25^{\circ} \mathrm{C}$ for 7 days. Phytopathogenic fungal growth was measured and compared with control plates without endophytic fungi. The colony diameters $(\mathrm{Cm})$, were measured and classified the according to following scale: $\mathrm{T}$ Total inhibition (0); P-Partial inhibition (1-2.0); NNo inhibition $(\geq 2.1)$. The experiment was repeated twice with three replicates.

\section{Biofumigation with endophytic fungi from coffee}

The VOCs produced by endophytic fungi were tested against A. ochraceus (SCM 1.15), producer of sclerotia and ochratoxin A in coffee beans (coffee in the dried bean and hulled coffee), isolated belonging to the Culture Collection of the Departament of Food Sciences (CDCA; Federal University of Lavras, Minas Gerais, Brazil), and $F$. verticillioides (CML1896), in corn seeds. Coffee beans and corn seeds were surface disinfested by immersion in $70 \%$ ethanol for $3 \mathrm{~min}$, sodium hypochlorite at $2.5 \%$ for $5 \mathrm{~min}$ and three times with sterile distilled water. After air-dying the beans and corn seeds, they were inoculated by immersion in a suspension of A. ochraceus $\left(1.5 \times 10^{5}\right.$ conidia $\left./ \mathrm{mL}\right)$ and $F$. verticillioides $\left(2.0 \times 10^{5}\right.$ conidia/mL) spores, respectively. In bipartite Petri dishes containing PDA medium, the endophytes were cultivated for 7 days at $25^{\circ} \mathrm{C}$. After this period, coffee beans inoculated with $A$. ochraceus and corn seeds inoculated with $F$. verticillioides were placed on the other side of the plate. The effect of volatile compounds produced was evaluated by the presence or absence of growth in grains inoculated with $A$. ochraceus and $F$. verticillioides. The control treatment consisted of grains inoculated with plant pathogens without the presence of the endophytic fungi. To assess the fungistatic and fungicidal action of the volatile compounds the coffee grains and corn seeds, they were transferred to PDA medium after 7 days of exposure to volatile compounds. The experiment was repeated twice with three replicates. 


\section{RESULTS AND DISCUSSION}

\section{Endophytic fungi from Coffea arabica}

A total of 620 fragments were obtained from stems (391), leaves (113) and fruits (116) of the Coffea arabica. Among the 400 endophytic fungi isolated from stems (261), fruits (97), and leaves (42), eleven (stems 7 and leaves 4) were able to grow in the presence of VOCs produced by $M$. albus. Colonies of 11 endophytic fungi on PDA were white, cottony with slow growth and absence of sporulation. The fungi were identified as Muscodor coffeanum (3), Muscodor vitigenus (4), Muscodor yucatanensis (2) and Simplicilium sp. (2), according to searches in UNITE database using DNA sequences of internal transcribed spacer (ITS) (Table 1).

Table 1. Identification of the isolated endophytic fungi producing volatile compounds

\begin{tabular}{lcc}
\hline \multicolumn{1}{c}{ Isolate } & Origin & Accession no. \\
\hline M. coffeanum (COAD 1842) & Leaf & KM514680 \\
M.coffeanum (COAD 1899) & Leaf & KM514681 \\
M.coffeanum (COAD 1900) & Leaf & KP862879 \\
M. vitigenus (C20) & Stem & KU094049 \\
M. vitigenus (HZM10) & Stem & KU094053 \\
M. vitigenus (HZM39) & Stem & KU094054 \\
M. vitigenus (HZM41) & Stem & KU094055 \\
M. yucatanensis (HZM60) & Leaf & KU094055 \\
M. yucatanensis (HZM64) & Leaf & KU094056 \\
Simplicillium sp. (C18) & Stem & KU094050 \\
Simplicillium sp. (C12) & Stem & KU094051 \\
\hline
\end{tabular}

Muscodor is a genus of sterile endophytic fungi, all species of this genus were characterized by the production of volatile organic compounds (VOCs) that inhibit the growth of other microorganisms (STROBEL et al., 2001a; STROBEL, 2006b; STROBEL, 2011c; STINSON et al., 2003; MERCIER; JIMENEZ, 2004; MERCIER; MANKER 2005; MERCIER et al., 2007; WORAPONG; STROBEL, 2009; ZHANG et al., 2010; SUWANNARACH et al., 2012; KUDALKAR et al., 2012; SAXENA et al., 2015).

The specie $M$. vitigenus, identified in our study was first isolated from Paullinia paullinioides by Daisy et al. (2002). These authors report that this specie produces compounds such as styrene, benzaldehyde, butylated hydroxytoluene, toluene, naphthalene and a number of minor benzene derivatives and that the compound produced, naphthalene, causes modifications in insect behaviour.

Muscodor yucatanensis, one of the species herein identified, is a recognized producer of an intense musty odor. Colonies, when grown on PDA, usually form a whitish, flocculose colony with an uncolored reverse and a mycelium that grows slowly (GONZÁLEZ et al., 2009).

Two isolates of the genus Simplicillium also were identified in our study. The species $S$. lonosoniveum and S. lamellicola were isolated from coffee plants but not as endophytes and they have been exploited as biological control agent (ZARE et al., 2001; WARD et al., 2010).

Muscodor coffeanum reported in this study (COAD 1842, COAD 1899 and COAD 1900) is a new species isolated from leaves and stems from coffee plants in Brazil (HONGSANAN et al., 2015).

\section{Biological activity of the VOC's produced by endophytic fungi}

The action of volatile organic compounds produced by endophytic fungi was tested against a spectrum of phytopathogenic fungi and fungi associated postharvest diseases (Table 2). The VOCs produced by endophytic fungi exhibited 
antifungal activity with different efficiency. The phytopatogenic fungi $R$. solani, $C$. coffeicola and Phoma sp., were completely suppressed by VOCs produced by most endophytic fungi, whereas fungi like $B$. cinerea, $A$. ochraceus and $F$. verticillioides showed sensitivity to VOCs.

Previous works with VOCs produced by Muscodor albus presented antimicrobial potential against fungi, oomycetes and bacteria. The growth of Botrytis cinerea, Aspergillus fumigatus, Rhizoctonia solani, Sclerotinia sclerotiorum, Pythium ultimum, Verticillium dahliae, Phytophthora cinnamomi, Candida albicans, Escherichia coli, Bacillus subtilis and Staphylococcus aureus was inhibited or the fungi died after exposure to VOCs of $M$. albus (WORAPONG et al., 2001; STROBEL et al., 2001). Moreover, other Muscodor species have been described to inhibit the growth of fungi associated with post-harvest decay (MITCHELL et al., 2008).

None of the endophytic fungi showed total inhibition against $F$. oxysporum. Fusarium species may be less susceptible to VOCs (FIALHO et al., 2010). The VOCs produced by endophytic fungus M. yucatanensis were lethal to Colletotrichum sp., Phomopsis sp., Guignardia mangiferae, Phythophthora capsici, P. parasitica, Rhizoctonia sp., and Alternaria solani but there was no complete growth inhibition of $F$. oxysporum when compared with the control (MACÍAS-RUBALCAVA et al., 2010).

Strobel et al., (2001) also found similar results, among several tested fungi the phytopathogenic fungi Fusarium solani was more resistant to the VOCs produced by $M$. albus. In addition, the artificial mixtures of VOCs produced by Gliocladium sp. partially inhibited $F$. oxysporum (STINSON et al., 2003).

In our study, the VOCs produced by Simplicillium sp. (C12, C18) also exhibited antifungal activity, the isolate $\mathrm{C} 12$ completely inhibit the growth of $R$. solani, $C$. coffeicola and Phoma sp., whereas isolate C18 inhibited total growth of $C$. coffeicola. To our knowledge, our study is one of the few that has reported the antifungal activity of Simplicillium sp. through production of VOCs. Thus, these isolates may be candidates for more detailed studies involving biological control. Moreover, further studies are needed to understand how these compounds act and to know their effect on these organisms.

\section{Activity of VOCs against seed pathogens}

The endophytic fungus $M$. coffeanum (COAD 1842) showed fungicidal activity since it completely inhibited the mycelial growth of $A$. ochraceus. The endophytic fungi Simplicillium sp. (C12), M. coffeanum (COAD 1900) and $M$. coffeanum (COAD 1899) showed fungistatic activity. Endophytic fungi also showed growth inhibition of $F$. verticillioides in corn seeds. Among the eleven evaluated endophyte fungi the isolates $M$. coffeanum (COAD 1842), M. coffeanum (COAD 1899), M. coffeanum (COAD 1900), M. vitigenus (C20), Simplicillium sp. (C12) and Simplicillium sp. (C18) showed total growth inhibition of $F$. verticillioides (Table 3 ).

Coffee is an important commercial product, the fungus A. ochraceus is reported as producer of ochratoxin A (OTA) in coffee beans, and its presence, as well as the production of OTA in coffee, is undesirable because it may be used as a trade barrier, affecting the economies of producing countries (SUAREZ-QUIROZ et al., 2004). The fungi, producers of volatile compounds with broad antimicrobial activity, isolated from $C$. arabica have potential for biotechnological applications.

These findings open new possibilities for developing mycofumigation as a post-harvest treatment, since, Muscodor spp. and Simplicilium stand out as potential candidates as biocontrol agents in post-harvest technology constituting an alternative to replace chemical fungicides. Characterization studies on the bioactive metabolites of the potent fungal strains from $C$. arabica and their use as biocontrol agents are in progress.

Fusarium verticillioides is one of the most commonly reported soil-borne fungal pathogens infecting maize (Zea mays L.), one of the most important cereal grains grown worldwide. This fungus produces secondary metabolites such as fumonisins (FB), especially fumonisin B1 (FB1), which affects human and animal health (BACON et al., 1996). Since $F$. verticillioides is endophytic in maize and is almost universally associated with maize and maize products, it is very important to control this species in this agriculturally important commodity. Furthermore, root colonization by $F$. verticillioides has been considered the initiator of systemic infection that eventually results in the fungus producing fumonisins in kernels. Seed treatment with biocontrol agents is an appropriate method for biocontrol of soil-borne plant pathogens in the spermosphere and rhizosphere (KERRY, 2000). 
Table 2. Action of volatile organic compounds produced by endophytic fungi on growth inhibition of phytopathogenic fungi T-Total inhibition (0); P-Partial inhibition $(1-2.0 \mathrm{~cm}) ; \mathrm{N}$ - No inhibition $(\geq 2 \mathrm{~cm})$.

\begin{tabular}{|c|c|c|c|c|c|c|c|c|c|}
\hline \multirow{2}{*}{ Endophytic fungi } & \multicolumn{7}{|c|}{ Phytopathogenic fungi } & \multirow[b]{2}{*}{ Phoma sp. } & \multirow[b]{2}{*}{ P. longisetula } \\
\hline & B. cinerea & A. ochraceus & F. solani & R. solani & F. verticillioides & C. coffeicola & F. oxysporum & & \\
\hline M. coffeanum (COAD 1842) & $\mathrm{T}$ & $\mathrm{P}$ & $\mathrm{N}$ & $\mathrm{T}$ & $\mathrm{T}$ & $\mathrm{T}$ & $\mathrm{N}$ & $\mathrm{T}$ & $\mathrm{P}$ \\
\hline M. coffeanum (COAD 1899) & $\mathrm{T}$ & $\mathrm{N}$ & $\mathrm{P}$ & $\mathrm{T}$ & $\mathrm{T}$ & $\mathrm{P}$ & $\mathrm{N}$ & $\mathrm{T}$ & $\mathrm{T}$ \\
\hline M. coffeanum (COAD 1900) & $\mathrm{T}$ & $\mathrm{N}$ & $\mathrm{N}$ & $\mathrm{T}$ & $\mathrm{T}$ & $\mathrm{P}$ & $\mathrm{P}$ & $\mathrm{P}$ & $\mathrm{P}$ \\
\hline M. vitigenus (C20) & $\mathrm{P}$ & $\mathrm{N}$ & $\mathrm{N}$ & $\mathrm{T}$ & $\mathrm{T}$ & $\mathrm{T}$ & $\mathrm{N}$ & $\mathrm{T}$ & $\mathrm{T}$ \\
\hline M.vitigenus (HZM10) & $\mathrm{P}$ & $\mathrm{N}$ & $\mathrm{N}$ & $\mathrm{T}$ & $\mathrm{N}$ & $\mathrm{T}$ & $\mathrm{P}$ & $\mathrm{T}$ & $\mathrm{T}$ \\
\hline M. vitigenus (HZM39) & $\mathrm{P}$ & $\mathrm{N}$ & $\mathrm{N}$ & $\mathrm{T}$ & $\mathrm{N}$ & $\mathrm{T}$ & $\mathrm{N}$ & $\mathrm{T}$ & $\mathrm{T}$ \\
\hline M.vitigenus (HZM41) & $\mathrm{P}$ & $\mathrm{T}$ & $\mathrm{N}$ & $\mathrm{P}$ & $\mathrm{N}$ & $\mathrm{T}$ & $\mathrm{P}$ & $\mathrm{T}$ & $\mathrm{P}$ \\
\hline M.yucatanensis (HZM60) & $\mathrm{T}$ & $\mathrm{N}$ & $\mathrm{P}$ & $\mathrm{T}$ & $P$ & $\mathrm{~T}$ & $\mathrm{P}$ & $\mathrm{P}$ & $\mathrm{P}$ \\
\hline M. yucatanensis (HZM64) & $\mathrm{T}$ & $\mathrm{P}$ & $\mathrm{N}$ & $\mathrm{T}$ & $\mathrm{P}$ & $\mathrm{T}$ & $\mathrm{N}$ & $\mathrm{T}$ & $\mathrm{P}$ \\
\hline Simplicillium sp. (C12) & $\mathrm{P}$ & $\mathrm{N}$ & $\mathrm{P}$ & $\mathrm{T}$ & $\mathrm{P}$ & $\mathrm{T}$ & $\mathrm{N}$ & $\mathrm{T}$ & $\mathrm{P}$ \\
\hline Simplicillium sp. (C18) & $\mathrm{P}$ & $\begin{array}{l}N \\
-n\end{array}$ & $\mathrm{~N}$ & $\mathrm{P}$ & $\mathrm{N}$ & $\mathrm{T}$ & $\mathrm{N}$ & $\mathrm{P}$ & $\mathrm{P}$ \\
\hline
\end{tabular}


Table 3. Aspergillus ochraceus and Fusarium verticillioides inhibited by volatile organic compounds produced by endophytic fungi.

\begin{tabular}{lccc}
\hline \multicolumn{1}{c}{ Endophytic fungi } & $\begin{array}{c}\text { A. ochraceus in } \\
\text { Coffee in the } \\
\text { dried bean }\end{array}$ & $\begin{array}{c}\text { A. ochraceus in Hulled } \\
\text { coffee }\end{array}$ & $\begin{array}{c}\text { F. verticillioides in } \\
\text { corn seed }\end{array}$ \\
\hline M. coffeanum (COAD 1842) & + & + & + \\
M. coffeanum (COAD 1899) & \pm & \pm & + \\
M. coffeanum (COAD 1900) & \pm & - & + \\
M. vitigenus (C20) & - & - & + \\
M.vitigenus (HZM10) & - & - & \pm \\
M. vitigenus (HZM39) & - & - & \pm \\
M. vitigenus (HZM41) & - & - & \pm \\
M. yucatanensis (HZM60) & - & - & \pm \\
M. yucatanensis (HZM64) & - & \pm & \pm \\
Simplicillium sp. (C12) & - & & + \\
Simplicillium sp. (C18) & \pm & & \pm \\
\hline
\end{tabular}

Total inhibition (+); Partial inhibition ( \pm ); No inhibition (-).

\section{CONCLUSIONS}

Volatile compound producing endophytic fungi were isolated from $C$. arabica, among the 400 fungi, 12 isolates were able to grow in the presence of VOCs produced by M. albus.

The VOC producing fungi belong the genus Muscodor (9) Simplicillium (2) and Acremonium (1). The volatile compounds produced by $M$. coffeanum (COAD 1842) showed fungicidal activity against $A$. ochraceus and six isolates inhibited the growth of $F$. verticillioides.

The results demonstrate the potential of fungal endophytes from $C$. arabica with antimicrobial action, since, plant pathogens were inhibited or killed by endophytic fungi, producers of volatile organic compounds.

\section{ACKNOWLEDGMENT}

The authors would like to thank the Coordenação de Aperfeiçoamento de Pessoal de Nível Superior (CAPES), the Conselho Nacional de Desenvolvimento Científico e Tecnológico (CNPq) and the Fundação de Amparo à pesquisa do Estado de Minas Gerais (FAPEMIG) for financial support and scholarships.

RESUMO: Fungos endofíticos são uma fonte promissora para a descoberta de compostos com potencial biotecnológico. O objetivo deste estudo foi selecionar e identificar fungos endofíticos de Coffea arabica que produzem compostos orgânicos voláteis (COVs), avaliar o efeito dos compostos orgânicos voláteis produzido por fungos endofíticos sobre o crescimento de Rhizoctonia solani, Fusarium oxysporum, Phoma sp., Botrytis cinerea, Fusarium solani, Fusarium verticillioides, Cercospora coffeicola e Pestalotia longisetula e selecionar fungos endofíticos com potencial para controle biológico de Aspergillus ochraceus inoculado em grãos de café e $F$. verticillioides inoculado em sementes de milho. Um isolado de Muscodor albus foi utilizado como ferramenta de seleção para fungos endofíticos produtores de COVs. Dentre os 400 fungos endofíticos isolados, 11 foram capazes de crescer na presença de COVs produzidos por M. albus. Estes fungos foram identificados como Muscodor spp. (9) e Simplicillium sp. de acordo com pesquisas na base de dados UNITE usando sequências de DNA do espaçador transcrito interno (ITS). Os COVs produzidos por fungos endofíticos inibiram o crescimento dos fungos fitopatogênicos em comparação com o controle com diferentes eficácias. Os COVs produzidos por Muscodor coffeanum (COAD 1842) apresentou efeito fungicida contra A. ochraceus em grãos de café. Seis fungos endofíticos inibiram completamente o crescimento de $F$. verticillioides inoculado em sementes de milho. Este estudo demonstra que os fungos endofíticos produtores de compostos voláteis isolados de Coffea arabica são fontes promissoras de compostos bioativos. voláteis.

PALAVRAS-CHAVE: Aspergillus ochraceus. Fusarium verticillioides. Inibição. Muscodor spp. Compostos 


\section{REFERENCES}

AZEVEDO, J. L.; MACCHERONI JR, W.; PEREIRA, J. O.; DE ARAÚJO, W. L. Endophytic microorganisms: a review on insect control and recent advances on tropical plants. Electronic Journal of Biotechnology, Valparaíso, v. 3, n. 1, p. 15-16, 2000. https://doi.org/10.2225/vol3-issue1-fulltext-4

BACON, C. W.; HINTON, D. M. Symptomless endophytic colonization of maize by Fusarium moniliforme. Canadian Journal of Botany, Canada. v. 74, n. 8, p. 1195-1202, 1996.

https://doi.org/10.1139/b96-144

DAISY, B. H.; STROBEL, G. A.; CASTILLO, U.; EZRA, D.; SEARS, J.; WEAVER, D. K.; RUNYON, J. Naphthalene, an insect repellent, is produced by Muscodor vitigenus, a novel endophytic fungus. Microbiology, London, v. 148, n. 11, p. 3737-3741, 2002. https://doi.org/10.1099/00221287-148-113737

EZRA, D.; STROBEL, G. A. Effect of substrate on the bioactivity of volatile antimicrobials produced by Muscodor albus. Plant Science, Ireland. v. 165, n. 6, p. 1229-1238, 2003. https://doi.org/10.1016/S01689452(03)00330-3

FIALHO, M. B.; TOFFANO, L.; PEDROSO, M. P; AUGUSTO, F.; PASCHOLATI, S. F. Volatile organic compounds produced by Saccharomyces cerevisiae inhibit the in vitro development of Guignardia citricarpa, the causal agent of citrus black spot. World Journal of Microbiology and Biotechnology, Netherlands. v. 26, n. 5, p. 925-932, 2010. https://doi.org/10.1007/s11274-009-0255-4

GONZÁLEZ, M. C.; ANAYA, A. L.; GLENN, A. E.; MACÍAS-RUBALCAVA, M. L.; HERNÁNDEZBAUTISTA, B. E.; HANLIN, R. T. Muscodor yucatanensis, a new endophytic ascomycete from Mexican chakah, Bursera simaruba. Mycotaxon, Portland, v. 110, n. 1, p. 363-372, 2009.

https://doi.org/10.5248/110.363

GRIMME, E.; ZIDACK, N. K., SIKORA, R. A.; STROBEL, G. A.; JACOBSEN, B. J. Comparison of Muscodor albus volatiles with a biorational mixture for control of seedling diseases of sugar beet and root-knot nematode on tomato. Plant Disease, St. Paul, v. 91, n. 2, p. 220-225, 2007.

HALL, T. A. BioEdit: a user-friendly biological sequence alignment editor and analysis program for Windows 95/98/NT. In: Nucleic acids symposium series, Oxford, 1999. p. 95-98.

HONGSANAN, S.; HYDE, K. D.; BAHKALI, A. H.; CAMPORESI, E.; CHOMNUNTI, P.; EKANAYAKA, H.; PEREIRA, O. L. Fungal Biodiversity Profiles 11-20. Cryptogamie, Mycologie, Washington, v. 36, n. 3, p. 355-380, 2015. https://doi.org/10.7872/crym/v36.iss3.2015.355

HYDE, K. D.; SOYTONG, K. The fungal endophyte dilemma. Fungal Divers, Thailand. v. 33, n. 163173, p. $2,2008$.

KERRY, B. R. Rhizosphere interactions and the exploitation of microbial agents for the biological control of plant-parasitic nematodes. Annual review of phytopathology, Palo Alto, v. 38, n. 1, p. 423-441, 2000.

KOGEL, K.H.; FRANKEN, P.; HUCKELHOVEN, R. Endophyte or parasite-what decides?. Current opinion in plant biology, London, v. 9, n. 4, p. 358-363, 2006.

KUDALKAR, P.; STROBEL, G.; RIYAZ-UL-HASSAN, S.; GEARY, B.; SEARS, J. Muscodor sutura, a novel endophytic fungus with volatile antibiotic activities. Mycoscience, Japan, v. 53, n. 4, p. 319-325, 2012. https://doi.org/10.1007/S10267-011-0165-9 
MACÍAS-RUBALCAVA, M. L.; HERNÁNDEZ-BAUTISTA, B. E.; OROPEZA, F.; DUARTE, G.; GONZÁLEZ, M. C.; GLENN, A. E.; ANAYA, A. L. Allelochemical effects of volatile compounds and organic extracts from Muscodor yucatanensis, a tropical endophytic fungus from Bursera simaruba. Journal of chemical ecology, Florida, v. 36, n. 10, p. 1122-1131, 2010.

MERCIER, J.; JIMÉNEZ, J. I. Control of fungal decay of apples and peaches by the biofumigant fungus Muscodor albus. Postharvest Biology and Technology, Leuven, v. 31, n. 1, p. 1-8, 2004. https://doi.org/10.1016/j.postharvbio.2003.08.004

MERCIER, J.; MANKER, D. C. Biocontrol of soil-borne diseases and plant growth enhancement in greenhouse soilless mix by the volatile-producing fungus Muscodor albus. Crop Protection, Cotonou, v. 24, n. 4, p. 355-362, 2005.

MERCIER, J.; SMILANICK, J. L. Control of green mold and sour rot of stored lemon by biofumigation with Muscodor albus. Biological Control, Amsterdam, v. 32, n. 3, p. 401-407, 2005.

MERCIER, J.; JIMENEZ, J. I. Potential of the volatile-producing fungus Muscodor albus for control of building molds. Canadian journal of microbiology, Ottawa, v. 53, n. 3, p. 404-410, 2007.

https://doi.org/10.1016/j.biocontrol.2004.12.002

MITCHELL, A. M.; STROBEL, G. A.; HESS, W. M.; VARGAS, P. N.; EZRA, D. Muscodor crispans, a novel endophyte from Ananas ananassoides in the Bolivian Amazon. Fungal Diversity, Thailand, v. 31, p. 37-43, 2008.

NILSSON, R. H.; HYDE, K. D.; PAWŁOWSKA, J.; RYBERG, M.; TEDERSOO, L., A. B.; ARNOLD, A. E. Improving ITS sequence data for identification of plant pathogenic fungi. Fungal diversity, Thailand. v. 67, n. 1, p. 11-19, 2014.

PETRINI, O. Fungal endophytes of tree leaves. In: Microbial ecology of leaves. Springer New York, USA.1991. p. 179-197. https://doi.org/10.1007/978-1-4612-3168-4_9

SANTAMARÍA, J.; BAYMAN, P. Fungal epiphytes and endophytes of coffee leaves (Coffea arabica). Microbial Ecology, Rockville, v. 50, n. 1, p. 1-8, 2005. https://doi.org/10.1007/s00248-004-0002-1

SAUCEDO-GARCÍA, A.; ANAYA, A. L.; ESPINOSA-GARCÍA, F. J.; GONZÁLEZ, M. C. Diversity and communities of foliar endophytic fungi from different agroecosystems of Coffea arabica L. in two regions of Veracruz, Mexico. PloS one, California, v. 9, n. 6, p. e98454, 2014.

SAXENA, S.; MESHRAM, V.; KAPOOR, N. Muscodor tigerii sp. nov.-Volatile antibiotic producing endophytic fungus from the Northeastern Himalayas. Annals of Microbiology, Milan, v. 65, n. 1, p. 47-57, 2015. https://doi.org/10.1007/s13213-014-0834-y

SETTE, L. D.; PASSARINI, M. R. Z.; DELARMELINA, C.; SALATI, F.; DUARTE, M. C. T. Molecular characterization and antimicrobial activity of endophytic fungi from coffee plants. World Journal of Microbiology and Biotechnology, Hull, v. 22, n. 11, p. 1185-1195, 2006. https://doi.org/10.1007/s11274-0069160-2

STINSON, M.; EZRA, D.; HESS, W. M.; SEARS, J.; STROBEL, G. An endophytic Gliocladium sp. of Eucryphia cordifolia producing selective volatile antimicrobial compounds. Plant Science, Amsterdam, v. 165, n. 4, p. 913-922, 2003. https://doi.org/10.1016/s0168-9452(03)00299-1

STROBEL, G. A.; DIRKSE, E.; SEARS, J.; MARKWORTH, C. Volatile antimicrobials from Muscodor albus, a novel endophytic fungus. Microbiology, London, v. 147, n. 11, p. 2943-2950, 2001.

https://doi.org/10.1099/00221287-147-11-2943 
STROBEL, G. Muscodor albus and its biological promise. Journal of Industrial Microbiology and Biotechnology, Houston, v. 33, n. 7, p. 514-522, 2006. https://doi.org/10.1007/s10295-006-0090-7

STROBEL, G. Muscodor species-endophytes with biological promise. Phytochemistry Reviews, Dordrecht, v. 10, n. 2, p. 165-172, 2011. https://doi.org/10.1007/s11101-010-9163-3

SUÁREZ-QUIROZ, M.; GONZÁLEZ-RIOS, O.; BAREL, M.; GUYOT, B.; SCHORR-GALINDO, S.; GUIRAUD, J. P. Study of ochratoxin A-producing strains in coffee processing. International journal of food science \& technology, Christchurch, v. 39, n. 5, p. 501-507, 2004.

SUWANNARACH, N.; KUMLA, J.; BUSSABAN, B.; LUMYONG, S. Biocontrol of Rhizoctonia solani AG2, the causal agent of damping-off by Muscodor cinnamomi CMU-Cib 461. World Journal of Microbiology and Biotechnology, Hull, v. 28, n. 11, p. 3171-3177, 2012. https://doi.org/10.1007/s11274-012-1127-x

SUWANNARACH, N.; KUMLA, J.; BUSSABAN, B.; NUANGMEK, W.; MATSUI, K.; LUMYONG, S. Biofumigation with the endophytic fungus Nodulisporium spp. CMU-UPE34 to control postharvest decay of citrus fruit. Crop protection, Cotonou, v. 45, p. 63-70, 2013.

TAN, R. X.; ZOU, W. X. Endophytes: a rich source of functional metabolites. Natural product reports, Cambridge, v. 18, n. 4, p. 448-459, 2001.

TEJESVI, M. V.; NALINI, M. S.; MAHESH, B.; PRAKASH, H. S.; KINI, K. R.; SHETTY, H. S.; SUBBIAH, V. New hopes from endophytic fungal secondary metabolites. Boletín de la Sociedad Química de México, Del Benito Juárez, v. 1, n. 1, p. 19-26, 2007.

VEGA, F. E.; PAVA-RIPOLL, M.; POSADA, F.; BUYER, J. S. Endophytic bacteria in Coffea arabica L. Journal of basic microbiology, Jena, v. 45, n. 5, p. 371-380, 2005.

https://doi.org/10.3852/mycologia.98.1.31

VEGA, F. E.; POSADA, F.; PETERSON, S. W.; GIANFAGNA, T. J.; CHAVES, F. Penicillium species endophytic in coffee plants and ochratoxin A production. Mycologia, Tucson, v. 98, n. 1, p. 31-42, 2006.

WARD, N. A.; SCHNEIDER, R. W.; ROBERTSON, C. L. Field evaluations of Simplicillium lanosoniveum as a biological control agent for Phakopsora pachyrhizi. Phytopathology, Salinas, 100. (6): 134-134. 2010.

WHITE, T. J.; BRUNS, T.; LEE, S. J. W. T.; TAYLOR, J. W. Amplification and direct sequencing of fungal ribosomal RNA genes for phylogenetics. PCR protocols: a guide to methods and applications, San Diego, v. 18, n. 1, p. 315-322, 1990. https://doi.org/10.1016/b978-0-12-372180-8.50042-1

WORAPONG, J.; STROBEL, G. A. Biocontrol of a root rot of kale by Muscodor albus strain MFC2. BioControl, Sophia Antipolis Cedex, v. 54, n. 2, p. 301-306, 2009. https://doi.org/10.1007/s10526-0089175-8

ZARE, R.; GAMS, W. A revision of Verticillium section Prostrata. IV. The genera Lecanicillium and Simplicillium gen. nov. Nova Hedwigia, Stuttgart, v.73, n. 1, p. 1-50, 2001.

ZHANG, C. L.; WANG, G. P.; MAO, L. J.; KOMON-ZELAZOWSKA, M.; YUAN, Z. L.; LIN, F. C.; KUBICEK, C. P. Muscodor fengyangensis sp. nov. from southeast China: morphology, physiology and production of volatile compounds. Fungal biology, Manchester, v. 114, n. 10, p. 797-808, 2010. 